\title{
Evolution of Macau's Economy and Its Export-Oriented Industries
}

VICTOR F.S. SIT

Export-oriented industrialization has been regarded by many economists as an efficient way to attain economic growth for developing countries. The Newly Industrialized Countries (NICs) of Asia, i.e. South Korea, Taiwan, Hong Kong and Singapore, have often been quoted as such successful cases. Detailed investigations by some economists have revealed, however, different geo-political and historical factors behind each of them and cautioned against possible pitfalls of over-generalization that aims to propagate export-oriented industrialization as a panacea for lack of growth in the developing economies. James Petras has found that exportoriented industrialization generally leads to overconcentration of light manufacturing. ${ }^{1}$ Of 48 countries analysed, he found only seven that derived $30 \%$ or more of their manufacture value-added from industrial branches other than light industries. All seven, except India, are countries of 'middle income', suggesting that the deepening of industrialization is at least in part a product of the growing internal market. These countries are India, Kenya, Mexico, Brazil, Argentina, South Korea, and Singapore. The last country, Singapore, achieved such a rank mainly due to its refineries, shipbuilding and processing for tin and rubber which was a consequence of its location in Southeast Asia. The small internal market of countries such as Macau and Hong Kong has precluded them from the development of heavy industries.

Macau is one of those developing countries which have registered a rapid pace of economic development through export-oriented industrialization in the last two decades. However, Macau is little known, except for its world-class casinos, because of the small size of its economy and the general lack of published materials about it. Yet Macau shows some distinct character. Its industrial growth has been the outcome of its geo-political situation and its relationship 
with Hong Kong. Direct investment from the latter has played a large role in spearheading and shaping Macau's manufacturing, to the extent that Macau functions more or less as an extraterritorial outprocessing appendage of Hong Kong.

The present paper wants to fill the existing gap of information by piecing relevant facts together for a more complete, though largely descriptive, presentation of the modern export-oriented industrialization of Macau. First, it traces the evolution of the Macau economy, then the industrialization process in 1958-1986, and finally it discusses the major dynamics and characteristics of the process. Hopefully, it will improve our understanding of the varying factors behind the success of export-oriented industrialization in economic development in developing countries and add further substance to debates on economic development strategies for these economies.

In the presentation, developments in Macau have often been compared to those of Hong Kong. This is mainly because they are geographically adjacent and closely integrated economically, especially in manufacturing development. Of course Macau is much smaller than Hong Kong and in many respects dominated by it. Available data show that the GDP of Macau in 1986 was about 1 billion US dollars, compared to Hong Kong's 37.9 billion US dollars for the same year. As will be shown later, Macau not only takes lead from Hong Kong, it is very much overshadowed by it. Its industrialization is highly dependent on the excellent port of Hong Kong, its well developed financial and communication facilities as well as Hong Kong's capital, technology and entrepreneurial skills. The success of Macau's industrialization lies very much with its complementary role to Hong Kong deriving from its geo-political situation and close proximity to it. Therefore, on one hand, Macau industries share, to a large extent, the characteristics of Hong Kong industries, being labour-intensive, highly concentrated in textiles, garment and plastic goods, and small-scale in operation. On the other hand, dependence on Hong Kong has led to obvious defects in the Macau system such as insufficient demand for skill training, lack of innovativeness, inadequate development of supporting industries and a general short term view on future prospects.

Like Hong Kong, Macau has entered into a political transitional period. The Portuguese will return the administration of Macau to 
the local people in 1999 under an agreement with China signed in 1987. In the conclusion of the paper, the possible change in Macau's manufacturing arising from such change in political status will also be briefly discussed. In the light of such impending changes, a comprehensive review of its post Second World War industrial development should also be of practical planning merits.

\section{Evolution of Macau's Modern Economy}

Macau is a small Portuguese administered territory located at the western flank of the Pearl River Delta in South China. It has a total area of $16 \mathrm{~km}^{2}$ and a population of about 450,000 . To its east, about $64 \mathrm{~km}$ away and just about one hour jetfoil journey, on the eastern flank of the Pearl River Delta lies Hong Kong, a much 'larger' place with about $1,070 \mathrm{~km}^{2}$ territory and 5.6 million population.

Macau was obtained from the hands of corrupt Mandarins by Portugal in 1557 and since then served Portugal as a religious and trading outpost in the Far East till the Second World War. ${ }^{2}$ Its 'informal' political status ended in 1987, when the Chinese and Portuguese governments signed the Joint Declaration to transfer Macau's sovereignty back to China in 1999. The Joint Declaration promised preservation in Macau of the existing social, economic and legal systems as well as a high degree of self-rule for 50 years after 1999. Macau would become a Special Administrative Area of China, the same status Hong Kong will enjoy after 1997.

Immediately after the Portuguese occupation in 1557, Macau prospered as a thriving international trade centre and Portuguese religious outpost for roughly $80-90$ years. ${ }^{3}$ However, declining Portuguese influence and conflicts between Portugal and Spain caused major disruptions that ended the first epoch of prosperity in Macau. Macau enjoyed a second period of trade-derived prosperity again from 1717, when the Qing government in China closed all Chinese ports to foreign trade. ${ }^{4}$ This second epoch of prosperity was, however, terminated by the rising British influence in China since the turn of the 18th century and the establishment of Hong Kong in 1842. The shallow water in the port of Macau proved less 
attractive than the much wider and deeper Victoria Harbour of Hong Kong to the new generation of ocean ships powered by steam engines. Hence, Macau became almost a pond of dead water overtaken by Hong Kong, the new China entrepot and other new treaty ports along the China coast, and was gradually phased out as a member of significance in the international trade of the Far East.

Declining Portuguese influence in this part of the world and the rise of Hong Kong in its proximity only partly explained Macau's downfall as a major international trading centre. Its natural handicaps - the small size of the territory and the lack of a good natural harbour, as well as deficient modern facilities - were more important factors. Loss of the traditional trading role forced Macau to develop new means of survival, the so-called "special industries", i.e. gambling, prostitution, opium trade, and gold smuggling, taking advantage of its geographical location and special administrative status (The Chinese government forbade gambling and the Hong Kong government did the same except for horse racing and lottery). Gambling was, however, the more important of these as a means of public revenue. In the reign of Governor Isidora Francises Guimariaes (1851-63), in order to secure enough revenue in Macau, a licensing system for gambling houses was introduced. Then only Chinese games were allowed. ${ }^{5}$

Table 1. Composition of Macau's Export, 1930-1986 (in percent)

\begin{tabular}{lrrrrr}
\hline & 1930 & 1958 & 1969 & 1982 & 1986 \\
\hline Fish & 26.4 & 32.8 & 9.2 & 1.1 & 0.7 \\
Fire-crackers & 16.9 & 20.0 & N.A. & N.A. & N.A. \\
Matches & 15.9 & 3.8 & 7.1 & N.A. & N.A. \\
Incense & 6.0 & 4.7 & N.A. & N.A. & N.A. \\
Textiles \& & & & & & \\
garment & 5.3 & 19.0 & 71.6 & 76.8 & 69.7 \\
Food & 18.3 & 9.9 & N.A. & N.A. & N.A. \\
Artific. flower & N.A. & N.A. & N.A. & 3.6 & 2.8 \\
Toys & N.A. & N.A. & N.A. & 7.8 & 11.8 \\
Electronics & N.A. & N.A. & N.A. & 2.8 & 4.1 \\
Others & 12.0 & 9.8 & 12.0 & 7.9 & 10.9 \\
\hline
\end{tabular}

Source: Quarterly Economic Bulletin (March 1987). 
In 1934, Macau granted gambling monopoly to the Tai Xing Co. leading the further development of gambling in Macau. Throughout the 1930s, government tax from gambling activities yielded an annual revenue of about 1.5 million patacas, whereas the annual export amounted to about 10 million patacas. Among the exports in the 1930s (see Table 1) manufactured goods from three traditional crafts figured quite importantly. They were the making of matches, fire-crackers, and incense, all industries taking advantage of Macau's cheap labour, low import tax of the major raw materials required and tariff preferences granted by the USA. Indeed, these handicrafts had pioneered Macau's industrialization and remained the dominant export sectors well into the 1950s (see Table 1). In 1958 , they together with fish products accounted for $61.3 \%$ of the total exports. Their employment took $90 \%$ of the total manufacturing employment of 17,685 workers as revealed by an industrial survey in $1957 .{ }^{6}$

Macau's economy experienced a significant turn in the early 1950s. In 1952, the USA, the largest market for fire-crackers and incense, banned its import from Macau as part of its embargo on trade with China following the Korean War. In 1957, a new Portuguese legislation (Decree No. 41026) opened Portuguese territories and colonies to Macau exports with tax free treatment." Then, in 1961, a new law in Portugal decreed Macau as a "tourist city" and allowed it to operate western gambling. ${ }^{8}$ This train of events set Macau on a new course of development which laid the foundation of its present modern economy.

Thus, in 1962, the gambling business was reorganized. Added on top of the traditionally tolerated Chinese games was a full range of western casino games, and gambling was largely re-enfranchised and integrated with tourist development. ${ }^{9}$ The monopoly position and security offered by the new arrangement enabled Macau to attract investors with large capital resources. The monopoly has since been won by the Sociedade de Turismo e Diversoes de Macau (STDM) a largely Hong Kong owned enterprise. Through its efforts Macau has developed a new image as "The Monte Carlo of the Orient" serving a wide geographical area in the Far East where gambling is generally restricted, especially its crowded neighbour Hong Kong which became its main source of customers. As part of 
franchise conditions, STDM helped Macau develop its basic urban infrastructure, such as electricity, port facilities, external transport and communication with Hong Kong, and finance tourism and industrial export promotion offices and efforts. Gambling also provides Macau the largest source of the government's current revenue $(46.4 \%$ in the first half of 1986$) .{ }^{10}$ Together with tourism, gambling contributed 25\% of the GDP in 1985 (see Table 2). Hence modernization of the gambling sector has not only generated much government revenue and local employment and sparked off the complementary development of tourism, but also helped to improve the territory's physical and social infrastructure and its traisport links with Hong Kong, making Macau more attractive to exportoriented industries, particularly to investors from Hong Kong seeking cheap labour, cheap space and new export quotas.

Table 2. Origin of Macau's GDP, 1985

\begin{tabular}{lr} 
Manufacturing & 36.9 \\
Tourism, incl. gambling & 25.0 \\
Construction & 8.7 \\
Trade & 8.0 \\
Finance & 4.5 \\
Civil service & 3.1 \\
Energy & 1.9 \\
Fishery & 1.2 \\
Other & 10.7 \\
\hline
\end{tabular}

Source: Economic Intelligence Unit estimates, U.K. (1987)

The 1952 Decree which enabled Macau goods to have free entry into Portugal and its overseas colonies led to a major qualitative change in its manufacturing, which at present is the most significant sector of the economy. Manufacturing in 1986 provided close to half of the local jobs and generated $40 \%$ of the GDP whilst $90 \%$ of its output by value is exported, forming the largest foreign exchange earner as well. ${ }^{11}$

The economy as indicated in Table 2 , shows a heavy dependence on export-oriented manufacturing. The shadowy "special industries" of the early decades of the century, with the exception of gambling, have largely been phased out of significance. Even gambling is 
presently qualitatively different from what it was and is closely integrated with tourism which puts emphasis on recreation and sightseeing.

\section{Industrialization in Macau}

As Table 1 shows, the qualitative changes involved in Macau's industrialization can be divided into four phases: 1) early industrialization, 2) Portugal-led transformation, 3) phase of textiles and garments, 4) phase of diversification.

\section{Early Industrialization}

As has been said in the previous section, early industrialization of Macau was largely sparked off by the loss of Macau's trading role to Hong Kong and hence the need to find employment for the local population, which had increased to about 270,000 at around 1930, largely due to immigration caused by internal troubles inside China. This early phase of industrialization was founded mainly on cheap labour and low taxation on raw materials for fire-crackers and matches. At the time these handicrafts possibly formed the second largest employment sector, as about 60,000 persons were registered as belonging to the fishing population, likely to be the dominant employment sector. ${ }^{12}$

\section{Portugal-led Transformation}

The growth of modern industries was mainly due to Macau's loss of the USA market for its traditional handicraft products and new opportunities arising from the free movement of goods into Portuguese territories and colonies. The latter attracted many entrepreneurial Hong Kong businessmen as well as local industrialists to launch a new phase of industrial growth by setting up factories for production of light manufactured consumer goods for the Portuguese colonies and Portugal itself. The factories made use of the local cheap labour to produce textiles and wigs. At the height of this phase of industrialization, Portugal and its colonies became Macau's major export markets and took $56.7 \%$ of its total exports. 
Textiles contributed $19 \%$ of the total export, and the three traditional crafts still maintained a substantial share $(28.5 \%$, see Table 1$)$. However fish products, which are largely non-manufactured, still accounted for the largest share of the total export. The Portugal factor was truncated in the second half of the 1960s when Macau's 'duty free' privileges to enter Portugal and the Portuguese colonies were withdrawn.

\section{Phase of Textiles and Garments}

The major thrust in the development of modern manufacturing was steered by Hong Kong industrialists who under pressure of increasing restriction by European countries on their textile exports since the early 1960s sought to set up production facilities in Macau which was not yet under such restriction. Direct investment of this sort by Hong Kong industrialists at the time in other parts of the world, particularly in Taiwan and Southeast Asia has been treated by various authors, though there is little mention of Macau. ${ }^{13}$ The UK was the first country to impose trade restrictions on Hong Kong. Then came the EEC and USA, all in the early 1960s, and the restrictions largely applied to cotton textile products. Hence the growth rate of textiles in the 1960s in Macau was as high as $50 \%$ per annum. In 1969 and 1972-73, additional countries like Sweden and Canada followed suit. In 1972-75 trade restrictions on Hong Kong was furthermore extended to man-made fibres, woollen knitting, and knitted garments. A second wave of external stimuli came in 1976 when the USA introduced the General Preference Scheme (GPS) granting preferential tariff for selected products from developing countries. The new practice was soon taken up by the EEC, Canada and other developed countries. Hong Kong and Macau were among the 136 beneficiary countries of the scheme, yet important products such as garments and most electronic goods were excluded from Hong Kong. Investing in Macau therefore became a viable means for Hong Kong manufacturers for circumventing Hong Kong's exclusion.

The engine of growth for manufacturing in the second half of the 1960s and the 1970s was therefore apparently textiles and garments whose combined share of Macau's total export soared from $58.2 \%$ in 1970 to the all time high of about $90 \%$ in $1979 .{ }^{14}$ Fuelled by 
textiles and garments, manufacturing in Macau experienced an unprecedented annual growth rate of $27 \%$ with an overall increase of total exports of 29-fold in the period. The destination of exports changed accordingly. The EEC rose to a predominant position in $1975-80$, accounting for $50 \%-60 \%$ of total exports by value.

\section{Phase of Diversification}

In the 1980s, Macau's manufacturing sector sought to diversify under new exogeneous factors. Overconcentration on textiles and garments proved dangerous as Macau was soon put under restraining measures by its major overseas markets. The latest round (1982) of such restraining agreements straight-jacketed the annual growth of textile products to no more than $6 \%$. Secondly, another wave of growth due to the transfer of industrial capacity from Hong Kong happened since 1979, when industrialists there found that their advantages in a range of exports of manufactured goods e.g. toys and artificial flowers, under the GPS were being reduced or withdrawn (for toys the withdrawal came in 1981). Having learned from previous experience of the textiles and garments quota restrictions, many such industrialists closed their production facilities in Hong Kong and re-installed them in Macau where the GPS advantage for these products still existed. ${ }^{15}$ These newly arrived export sectors in Macau, composed of toys, artificial flowers, electronics and leather articles, made up $31 \%$ of the total export in 1985, a sharp rise from Macau's less than $1 \%$ in 1977. The most spectacular example is artificial flowers; this production was started in Macau in 1979, and its export growth in the three years that followed were respectively $400 \%, 200 \%$ and $100 \%$. However, in 1986, an upsurge of textiles and garments temporarily reduced the share of the new sectors to about $20 \%$ (see Table 1). The composition of the export markets duely reflected the above changes, with increasing eminence of the USA to reach near parity with the EEC 


\section{Dynamics of Industrial Growth}

The free trade policy and the dire situation of lack of resources and employment alternatives other than the gambling business have been obvious factors driving Macau towards establishing exportoriented manufacturing, taking advantage of its proximity to Hong Kong and its own special political and administrative status that had repeatedly won it separate quotas and special tariff treatment in the world's major markets for light industrial products. Feitor, in his work on Macau's modern economy, listed five major factors for the growth of Macau's modern economy, all of which are relevant to the development and expansion of manufacturing:

1 Favourable geographical location, especially the proximity to Hong Kong, enabling the benefit of spill-over effects of its development, and to Mainland China, providing a cheap source of food and other necessities and raw materials.

2 Liberal economic system, with limited government intervention and very low tax burden.

3 Existence of a nucleus of dynamic entrepreneurs with a positive attitude towards risk-assumption and a reasonable knowledge of the export markets.

4 High elasticity of labour supply, which has allowed wage levels to be kept comparatively low, coupled with the relatively high quality of labour for jobs not very demanding in skills.

5 Comparatively favourable access to foreign markets. ${ }^{16}$

Feitor's five factors require careful scrutiny. For example factors 1 and 5 would only be meaningful when interpreted in terms of Macau's separate quota and favourable tariff treatment by some overseas markets and its proximity to Hong Kong. The last fact is important for the translation of such advantages into development of export-oriented manufacturing. This is because Macau possesses neither an airport nor an international harbour, prime requirements for export-oriented industrial development for a small territory with no raw material resource. Indeed, geographically, Macau is much handicapped by its poor harbour and perennial silting problem, its 
location off the tracks of international shipping and its lack of railway link with south China. Most of Macau's trade has to go through Hong Kong thus adding to the time and money costs due to the transshipment involved.

Direct foreign investment from Hong Kong is believed to account for at least $60 \%$ of the industrial activities of Macau, though up until now no exact figures on such has been available. ${ }^{17}$ In a survey done in 1982 on 32 Hong Kong industrial firms that had invested in manufacturing in other Asian countries (not including Macau), Chen found that the two top motivations for deciding to invest overseas by Hong Kong firms are 'shortage of labour supply in Hong Kong' and 'high labour costs in Hong Kong' while 'to facilitate the export of products to third-part countries' closely followed as a third factor. ${ }^{18}$ Although Chen did not clearly define the third motivation, it may be reasonably taken as quota or tariff attraction of the host country for exporting the finished product. Indeed, Chen did list out 'to circumvent tariffs and quotas imposed by developed countries' as an eighth motivation which scored about half the frequencies (or significance) as any of the first three motivations. Direct foreign investment in Macau by Hong Kong industrialists seems to follow quite closely this overall pattern of motivations of Hong Kong multinationals to invest overseas. It is a pity that Macau mostly has not been included in such investigations. Due to Macau's proximity to Hong Kong, the volume and intensity of direct Hong Kong investment should be the most important factor behind Macau's industrial development as has been generally admitted. However, other than the time correlations between incidences of imposition of new quotas, tariff or trade restraint measures on Hong Kong exports and the rapid growth of the same type of industrial export in Macau, there is a lack of precise and direct quantitative information on the amount and nature of direct foreign investment by Hong Kong businessmen in Macau manufacturing, except the ' $60 \%$ ' figure quoted in this paragraph earlier on. In two recent surveys of factories in Macau organized in the summer of 1987 for unravelling the business characteristics of Macau industries, some indirect evidence on the extent of foreign ownership of Macau industries have been found. ${ }^{19}$ Out of 100 cases of successful interviews of factories employing 1- 
100 workers, 4 were owned by Hong Kong bosses. The same survey also contacted 84 other small establishments whose owners were reported by interviewees as permanent residents of Hong Kong and were not available for interview. Based on these, it may be guessed that $25-36 \%$ of the small factories are owned by Hong Kong residents. The second survey had contacted 25 medium to large factories, of which 14 (or 56\%) were owned by Hong Kong based interests. It may indicate that the large factories are most likely to be owned by Hong Kong interests. The validity of Feitor's third factor, the existence of a dynamic entrepreneurial class in Macau, is therefore much open to doubt.

Thus among Feitor's factors, the more important is number 5 favourable access to foreign markets 'compared' to Hong Kong. In textiles and garments, Hong Kong enjoys the largest share of import quotas in North American and EEC markets. Despite this, the quotas do constrain the pace of growth in these industries. Macau's quotas in such markets, though much smaller in size compared to Hong Kong's, are nevertheless adequate incentives for some of Hong Kong's operators in these industries to expand production in Macau or set up subcontracting linkages there (as have been revealed in the Hong Kong report on SMI development) as well as raison d'être for Macau entrepreneurs to venture into export manufacturing, copying the example of their Hong Kong counterparts. At present two thirds of the exports of Macau's dominant textiles and garments sectors are under restraining measures of the quota system. This is to say that about $45 \%$ of manufacturing exports of Macau are 'quota exports', indicating the significance of Macau's share of quotas in its drive in industrialization. ${ }^{20}$ Attraction of the GPS, adopted by the various industrialized nations since 1976 likewise played a significant role to garments and the other new industries as previously mentioned. In total, exports under the GPS system amounted to $13.2 \%$ of total exports (available figure at 1982, see Table 3). It included $95.2 \%$ of the toy production, $85.5 \%$ of the artificial flowers and more than half of furniture and optical instruments. To a large extent, development and growth of these industries were related to the existence of the GPS system. Of the industrialized countries which adopted the system the majority have already renewed its validity until 1990 . The system will therefore 
continue to be a significant factor of growth for Macau exports, especially so when the most important of the GPS granting countries, the USA has withdrawn in January 1988 its preferential treatment altogether under the GPS from the four Asian NICs (Singapore, South Korea, Taiwan and Hong Kong) all keen competitors of Macau exports.

Table 3. Macau's Exports under the GPS System of Preferences

\begin{tabular}{lccr}
\hline Items & $\begin{array}{c}\text { Total amount } \\
\text { (million p.) }^{\mathrm{a}}\end{array}$ & $\begin{array}{c}\text { Percent of } \\
\text { Total exp. }\end{array}$ & $\begin{array}{c}\text { Percent of } \\
\text { GPS exp. }\end{array}$ \\
\hline Textiles and garments & 116 & 8.4 & 19.6 \\
Artificial flowers & 115 & 85.5 & 19.5 \\
Ceramics & 7 & 20.2 & 1.2 \\
Electronics & - & - & - \\
Furniture & 12 & 56.5 & 2.1 \\
Toys & 266 & 95.2 & 45.1 \\
Optical instruments & 19 & 59.8 & 3.3 \\
Others & 55 & 12.9 & 9.2 \\
\hline Total & 591 & 13.2 & 100.0 \\
\hline
\end{tabular}

Source: Government of Macau, Sectorial Policies, Investment Plans (Public Sector) 1984 (Macau, 1984), p. 98.

${ }^{\mathrm{a}}$ p. = patacas. Eight patacas is about one US dollar.

Of course, high factor costs of land and labour in Hong Kong add to the steepness of the attraction gradient which pulled some manufacturing industries away from Hong Kong into Macau. Labour cost in Macau is estimated to be $40 \%$ less than in Hong Kong, while land and factory rental are reportedly $30 \%$ lower. ${ }^{21}$ Corporate profit tax in Macau is $15 \%$, lower than the $16.5 \%$ charged in Hong Kong. Yet the edge of real cost saving is slim, as there are additional costs involved in operating in Macau, such as transportation of raw materials, parts and components, and finished products between Macau and Hong Kong, higher communication costs (long distance telephone calls), an extra charge of $1.2 \%$ FOB value for certificate of origin for products exported under the quota system, higher electricity costs and much more bureaucracy than in Hong Kong. 
In more recent years, it had been the supply of labour (in addition to its lower cost) that had sustained Macau as an attractive location for some Hong Kong industrial firms, due largely to immigration from the PRC. However, as an industrial centre, Macau suffers from lack of skilled labour, insufficient number of indigenous entrepreneurs and inadequate industrial support services. At present, the majority of factories in Macau are believed to be owned and operated by Hong Kong entrepreneurs, with their management and technical supervisors brought in from Hong Kong. Up-grading training at the operative level is equally deficient, rendering a low rate of growth in labour productivity, i.e. annually at $2 \%$ in 1979-82, compared to $6 \%$ in $1980-86$ in Hong Kong. ${ }^{22}$ Such poor achievements are obviously both the consequence of the small size and hence the lack of scale economies for the provision of support services, lack of 'effective demand' as such needs may be more easily fulfilled by 'imports' from Hong Kong, as well as a government lukewarm in the promotion of manufacturing.

\section{Characteristics of Macau Manufacturing}

The demand side characteristics of Macau manufacturing have been previously revealed. Export-orientation, the concentration of demand in a few advanced economies as well as fluctuations in terms of product and market groups in time sequence and the relationship between these and Hong Kong investment have been discussed in some details. Within Macau itself, manufacturing at present is heavily dominated by garments and textiles (Table 4). According to the latest Industrial Survey (1984) available, garments accounted for $48.6 \%$ of manufacturing employment, $48.1 \%$ of gross output, and $44.9 \%$ of value-added in manufacturing. It was followed by a much smaller textiles sector which accounted for $15 \%$ of employment, $21.6 \%$ of gross-output, and $18.8 \%$ of value-added in manufacturing. These two industries therefore dominated manufacturing in Macau. 
Table 4. Industrial Production Statistics of Macau, 1984

\begin{tabular}{|c|c|c|c|c|c|c|c|}
\hline Industry & $\begin{array}{l}\text { ISIC } \\
\text { No. }\end{array}$ & $\begin{array}{l}\text { Units } \\
\text { (no.) }\end{array}$ & $\begin{array}{r}\text { Employ- } \\
\text { ment } \\
\text { (Persons) }\end{array}$ & $\begin{array}{r}\text { Gross } \\
\text { Output } \\
(1,000 \text { p. })^{a}\end{array}$ & $\begin{array}{r}\text { Value- } \\
\text { added } \\
(1,000 \text { p. })\end{array}$ & $\begin{array}{r}\text { Wage } \\
\text { bill } \\
(1,000 \text { p. })\end{array}$ & $\begin{array}{r}\text { Material } \\
\text { consumption } \\
(1,000 \mathrm{p} .)\end{array}$ \\
\hline Textiles & 321 & 124 & 8,825 & 126,949 & 325,986 & 143,922 & 939,508 \\
\hline Garment & 323 & 410 & 28,693 & $2,820,332$ & 777,898 & 406,259 & $2,042,434$ \\
\hline Footwear & 323.4 & 28 & 1,695 & 131,677 & 54,968 & 28,023 & 76,708 \\
\hline Wood \& cork & 331 & 35 & 248 & 12,186 & 6,523 & 2,992 & 5,663 \\
\hline Furniture & 332 & 46 & 783 & 42,086 & 18,803 & 12,512 & 23,283 \\
\hline $\begin{array}{l}\text { Paper \& } \\
\text { paper prod. }\end{array}$ & 341 & 34 & 476 & 57,130 & 14,996 & 7,321 & 42,134 \\
\hline $\begin{array}{l}\text { Printing \& } \\
\text { publishing }\end{array}$ & 342 & 51 & 910 & 47,803 & 22,018 & 16,522 & 25,784 \\
\hline Plastics & 356 & 56 & 4,999 & 452,039 & 162,576 & 76,667 & 289,463 \\
\hline $\begin{array}{l}\text { Pottery } \\
\text { glass }\end{array}$ & 361.2 & 20 & 656 & 46,358 & 25,207 & 13,000 & 21,150 \\
\hline $\begin{array}{l}\text { Fabricated } \\
\text { metal }\end{array}$ & 381 & 78 & 2,224 & 219,659 & 79,367 & 34,835 & 140,292 \\
\hline $\begin{array}{l}\text { Electrical \& } \\
\text { electronics }\end{array}$ & 383 & 30 & 2,217 & 160,374 & 34,871 & 27,119 & 125,503 \\
\hline Transp. eq. & 384 & 32 & 510 & 36 & 17,251 & 14,027 & 18,936 \\
\hline $\begin{array}{l}\text { Precision \& } \\
\text { scient. eq. }\end{array}$ & 785 & 10 & 938 & 61,898 & 24,393 & 13,619 & 37,505 \\
\hline Other & & 213 & 5,836 & 508,287 & 167,168 & 82,636 & 345,124 \\
\hline All manufact. & & 1167 & 59,001 & 5865511 & 1732025 & 879454 & 4133487 \\
\hline
\end{tabular}

Source: Compiled from Recenseamento Industrial 1984 (Census of Industry, 1984) (Macau: Macau Government).

${ }^{a}$ p. = patacas. Eight patacas is about one US dollar.

In the 1984 Industrial Census, 410 garment factories were reported, though it is believed that there are hundreds of small family workshops that might have been excluded from the Census. ${ }^{23}$ About $80 \%$ of the garment output was exported to markets covered by the Multi-Fibre Agreements. The textiles sector is largely composed of small woollen knitters which numbered about $100 ; 60-70 \%$ of the output from them are exported to markets with quota arrangements $\left(69.2 \%\right.$ in 1984 and $64.2 \%$ in 1985). ${ }^{24}$ However, the largest woollen knitter alone employed about 3,000 workers. Other textile factories are few in numbers. There were five woollen spinning mills in 1984, with about 2,000-3,000 employees; one silk-weaver with 250 employees; one cotton-weaver; two textile finishing factories; and about 15 stenciling factories. The paucity of supporting textile 
industries reflects the lack of economies of scale as market demand for their products or processes in Macau is small. Most of the supporting processes are therefore done in Hong Kong, leaving Macau highly concentrated in final processing for the finished goods.

Plastics form the third largest industry. It accounted for $8.5 \%$ of the employment, $7.7 \%$ of gross output and $9.4 \%$ of value-added in manufacturing in 1984. Toys are the main products of the plastics sector. Its growth was spurred by the withdrawal in 1981 of GPS treatment on Hong Kong exports by a number of countries, including Hong Kong's major markets, the USA and UK. At present about half of the toy export of Macau goes to the USA market. ${ }^{25}$

The fourth industry is electrical and electronics which accounted for $3.8 \%$ of employment, $2.7 \%$ of gross output and $2 \%$ of valueadded in manufacturing. The first electronics factory was established in the early 1970s and the industry's impetus of growth came since the late 1970s. In 1983 France forced an import restraint on Hong Kong exports of electronic watches which gave further stimulus to the development of the industry in Macau. At present $90 \%$ of the industry's output by value are composed of radio and cassette recorders, out of which $67.4 \%$ (in 1985) were exported to France where Macau enjoys no export restraint for these categories of goods. ${ }^{26}$

Other industries in Table 4 made up a minor part of the industrial system in Macau, in terms of employment, output and value-added.

When the statistics of the 1984 Censeamento Industrial are analysed further (Table 5), additional characteristics of Macau's manufacturing can be observed.

First, the size of the establishment is larger than the comparable figure in Hong Kong. This may be due to the fact that many of the smaller establishments (i.e. household factories of less than 5 persons) have not been included in the Census. Or it may be due to the lack of a widely developed subcontracting and supporting network of smaller firms in Macau as factory operations there seem more inclined toward labour-intensive type of final processing (e.g. comparable average establishment size for textiles, garments, plastics and electronics in Hong Kong in 1986 are respectively 23, $29,16,69$ persons). This has been confirmed by the surveys done in 
1987. In the Macau sample of 100 small and medium scale factories, only 16 were found to receive subcontracts from other factories, while in a Hong Kong sample of 292 similar size factories $29.4 \%$ are subcontractors. ${ }^{27}$

Table 5. Characteristics and Cost Structure of Selected Industries, 1984

\begin{tabular}{|c|c|c|c|c|c|c|}
\hline \multirow{2}{*}{$\begin{array}{r}\text { Textiles } \\
\text { emplo } \\
\text { (pe }\end{array}$} & \multirow{2}{*}{$\begin{array}{l}\text { verage } \\
\text { yment } \\
\text { ersons) }\end{array}$} & \multirow{2}{*}{$\begin{array}{r}\text { Gross output } \\
\text { per person } \\
\text { (employed) }\end{array}$} & \multirow{2}{*}{$\begin{array}{r}\text { Census } \\
\text { value-added } \\
(\% \text { of G.O. })^{a}\end{array}$} & \multicolumn{3}{|c|}{$\begin{array}{l}\text { Cost consumption } \\
\text { (\% of gross output) }\end{array}$} \\
\hline & & & & $\begin{array}{r}\text { Labour } \\
\text { cost }\end{array}$ & Consumption & $\begin{array}{l}\text { Rental, depre- } \\
\text { ciation, profit }\end{array}$ \\
\hline Textiles & 71.2 & $143,800(254,243)$ & $25.7(33.8)$ & $11.3(16.5)$ & $74.0(67.8)$ & $14.7(15.7)$ \\
\hline Garments & 70.0 & $98,300(137,872)$ & $27.6(41.8)$ & $14.4(25.9)$ & $72.4(60.8)$ & $13.2(13.3)$ \\
\hline Plastics & 89.3 & $90,425(201,500)$ & $36.0(39.4)$ & $17.0(18.8)$ & $64.0(61.3)$ & $19.0(20.0)$ \\
\hline Fabr. metals & 28.5 & $98,767(149,132)$ & $36.1(42.7)$ & $15.9(22.4)$ & $63.9(58.2)$ & $20.2(19.3)$ \\
\hline $\begin{array}{l}\text { Electrical \& } \\
\text { electronics }\end{array}$ & 73.9 & $72,338(224,638)$ & $21.7(40,8)$ & $16.9(17.3)$ & $78.3(55.7)$ & $4.8(27.0)$ \\
\hline
\end{tabular}

a Census value-added $=$ gross output less consunption.

${ }^{b}$ Includes raw materials, water electricity, fuel, maintenance, and industrial services.

Bracket fugures are comparable figures in Hong Kong manufacturing for 1985.

Source: Recenseamento Industrial 1984 (Census of Industry, 1984) (Macau: Macau Government).

Secondly, the value-added of Macau manufacturing as a percentage of gross output was $29.5 \%$, substantially lower than Hong Kong $(37.7 \%)$, indicating that Macau has more assembling industries where the larger local input is labour of lower skill-level. The cost composition of the selected industries and that of the whole manufacturing sector have been worked out as a percentage of gross output. However, no separate information on rental and depreciation was recorded in the Census, so these are lumped together with profit as a residual category (Table 5). The bulk of costs was accounted for by consumption of materials, water, fuels, electricity and industrial services. The percentages registered by all Macau industries underneath this column in the table were significantly higher than those registered in Hong Kong. Additional transfer cost from Hong Kong where most of these materials were initially imported or made, plus higher electricity and water rates may be the reasons behind. However, Macau was compensated to a great extent by much lower labour costs, especially so for the predominant garments and textiles industries. Labour costs as a percentage of 
gross output were quite close between Macau and Hong Kong for plastics and electrical and electronics. Comparative scarcity of local supporting industries for making parts and components as well as processing services are major reasons behind the overall lower percentages in value-added, particularly so in garments and electrical and electronics. In Hong Kong where data on 'rents and rates for land and buildings', 'rentals for hiring machinery and equipment' and 'other operating expenses' are available in the aggregate figure "other expenses", we can estimate the amount of depreciation and profit as percentage of gross output. For the entire manufacturing and the selected industries, these were (in 1985): all manufacturing $8 \%$; garments $4.1 \%$; textiles $7.9 \%$; plastics $11.0 \%$; fabricated metals $10.1 \%$ and electronical and electronics $13.1 \%$. With the large residual percentages, in electronical and electronics, the possibility of sizeable spending on depreciation in these industries is highly feasible. Thus we may infer that the electronics industry in Macau, when compared with Hong Kong, appears to belong to a lower level in technological scale as evidenced by its cost composition.

The above characteristics are supported by a much lower value in average gross output per employed person in Macau factories (Table 5). For manufacturing as a whole Macau was roughly 50\% of Hong Kong, and was much lower for electrical and electronics. Of course, lower percentage of value-added, higher costs of consumption of materials and other non-labour inputs and lower per capita gross output all reflect that Macau industries belong to a lower skill level, and are of cheap labour assembling or simple processing types of activities. Macau, as previous paragraphs have illustrated, survives to a large extent as an adjunct to the Hong Kong industrial system. Like other Kong Kong direct overseas investments in manufacturing, most Hong Kong owned operations exploit the labour factor of the host country, and hence the logical tendency of Macau manufacturing to be even more biased towards low technology, labour intensive assembling activities than Hong Kong. As Macau is about $1 / 10$ th Hong Kong's size in terms of total manufacturing employment and $1 / 30$ th in value of manufacturing gross output, factors of small size and geographical proximity render its dependence on Hong Kong inevitable and much more so 
than other countries which serve as hosts for direct Hong Kong investment. This also accounts to some extent for its shallow depth in industrialization.

\section{Role of Small and Medium Factories}

Since Macau manufacturing relies significantly on Hong Kong, almost to the extent that it may be regarded as an overspill of Hong Kong industries, it is expected to share the other characteristics of Hong Kong style export-oriented industries, i.e. a system of activities dominated by small scale factories with market-oriented type of subcontracting emphasizing on price competitiveness, quick delivery and flexibility. ${ }^{28}$ Detailed breakdown of manufacturing establishments in Macau according to size of employment is available only up to 1984 . Even so, the summary report of the Recenseamento Industrial $1984^{29}$ provides only scant information. It just mentioned that $53 \%$ of the 1,167 industrial establishments reported in the survey employed less than 20 persons, and $28 \%$ employed below 5 persons. Official information later than 1984 available is the list of industrial establishments in 1987. According to that list, out of 839 industrial establishments, 578 , or $68.9 \%$, employed 0-50 persons; 132 or $13.7 \%$ employed $50-100$ persons, and 129 or $15.4 \%$ employed 101 or more persons. Thus, more than eight out of ten of the listed factories in 1987 were small and medium size establishments. Of course, the 1987 list is by no means complete nor is it absolutely accurate. It is generally believed that there are around 1,000-5,000 household workshops that have not been included in the government's industrial censuses. We have, however, to leave the contention that there exists a large number of unreported petty factories aside and to turn to the only logical choice by following statistics revealed by industrial censuses of various dates, the earliest of which covers 1978 and the latest (with size-breakdown of the establishments) 1983.

Table 6 shows the distribution of the size sectors in manufacturing by numbers of establishments, employment, gross output value, and value-added in 1978-83. The number of establishments 
Victor F.S. Sit

Table 6. Significance of the Size Sector in the Manufacturing System of Macau, 19781983

\begin{tabular}{lrrrrrrr}
\hline & 1978 & 1979 & 1980 & 1981 & 1982 & 1983 & 1984 \\
\hline $\begin{array}{l}\text { 1. Establishment (\%) } \\
\text { Total (absolute no.) }\end{array}$ & $(864)$ & $(1.113)$ & $(1.118)$ & $(1,088)$ & $(1,155)$ & $(1,167)$ & \\
\hline & & & & & & & \\
$0-9$ & 48.1 & 55.7 & 52.3 & 47.2 & 43.0 & 41.4 & N.A. \\
$10-49$ & 26.4 & 22.6 & 22.0 & 24.4 & 26.7 & 27.1 & N.A. \\
$50-99$ & 13.5 & 9.8 & 10.5 & 10.8 & 12.5 & 13.3 & N.A. \\
$100-199$ & 7.6 & 8.9 & 11.3 & 12.3 & 12.1 & 13.0 & N.A. \\
$200-499$ & 3.9 & 2.8 & 3.6 & 4.8 & 4.8 & 4.7 & N.A. \\
500 and over & 0.3 & 0.3 & 0.3 & 0.4 & 0.5 & 0.4 & N.A. \\
\hline
\end{tabular}

\begin{tabular}{lrrrrrrr} 
2. Employment $(\%)$ \\
$\begin{array}{lrrrrr}\text { Total (absolute } \\
\text { no. in persons) }\end{array}$ & $(36,360)^{\mathrm{a}}$ & $(39,799)$ & $(46,962)$ & $(53,158)$ & $(59,306)(61,212)$ & N.A. \\
\hline & & $(45,212)$ & $(51,236)$ & $(59,336)$ & $(66,075)(67,103)$ & N.A. \\
\hline $0-9$ & 5.2 & 5.5 & 4.7 & 3.6 & 3.1 & 1.9 & N.A. \\
$\mathbf{1 0 - 4 9}$ & 14.7 & 15.1 & 12.7 & 11.4 & 12.0 & 11.7 & N.A. \\
$\mathbf{5 0 - 9 9}$ & 23.5 & 19.7 & 18.1 & 15.5 & 17.3 & 17.5 & N.A. \\
$\mathbf{1 0 0 - 1 9 9}$ & 25.4 & 33.7 & 36.1 & 34.6 & 31.9 & 33.4 & N.A. \\
$\mathbf{5 0 0}$ and over & 6.4 & 5.1 & 4.8 & 7.6 & 9.0 & 8.2 & N.A. \\
\hline
\end{tabular}

\begin{tabular}{|c|c|c|c|c|c|c|c|}
\hline $\begin{array}{l}\text { Gross output (\% } \\
\text { Total (absolute } \\
\text { million patacas) }\end{array}$ & $(1,360)$ & $(1,961)$ & $(2,751)$ & $(3,886)$ & $(4,943)$ & $(5,865)$ & \\
\hline $0-9$ & 3.2 & 3.0 & 2.4 & 1.8 & 1,8 & 1.5 & N.A. \\
\hline $10-49$ & 10.3 & 11.2 & 8.9 & 7.6 & 9.0 & 8.5 & N.A. \\
\hline $50-99$ & 25.3 & 18.5 & 15.8 & 14.1 & 17.7 & 17.0 & N.A. \\
\hline 100-199 & 26.2 & 37.4 & 37.9 & 37.9 & 29.6 & 32.5 & N.A. \\
\hline $200-499$ & 28.5 & 24.2 & 28.8 & 30.6 & 30.7 & 30.6 & N.A. \\
\hline 500 and over & 6.4 & 5.8 & 6.2 & 8.0 & 11.2 & 9.9 & N.A. \\
\hline
\end{tabular}

4. Value-added $(\%)^{\mathrm{c}}$

Total (absolute

\begin{tabular}{lrrrrrrr} 
million patacas) & $(371)$ & $(487)$ & $(645)$ & $(782)$ & $(987)$ & $(1,171)$ & $(1,732)$ \\
\hline $0-9$ & 5.2 & 4.7 & 4.2 & 2.8 & 2.9 & 2.3 & N.A. \\
$10-49$ & 13.4 & 14.4 & 11.2 & 8.8 & 10.0 & 9.2 & N.A. \\
$50-99$ & 25.5 & 18.8 & 17.4 & 12.8 & 13.2 & 14.9 & N.A. \\
$100-199$ & 23.2 & 35.2 & 35.9 & 31.1 & 26.7 & 25.9 & N.A. \\
$200-499$ & 26.0 & 22.1 & 27.7 & 24.5 & 26.2 & 26.7 & N.A. \\
500 and over & 6.5 & 4.9 & 4.0 & 20.0 & 20.9 & 21.0 & N.A. \\
\hline
\end{tabular}

a Total worked from tables with size. ${ }^{\mathrm{b}}$ Total reported by the census.

c Worked out by deducting estimated non-manufacturing contribution from total industrial. An unknown number of firms might not have reported such values.

Source: Compiled from Recenseamento Industrial (various dates). 
has shown little growth during 1978-84. In fact it remained almost stagnant at around 1,100 establishments since 1979. This is a very strange phenomenon, reflecting incomplete coverage as well as a doubtful ground survey basis of the censuses, which nevertheless is difficult for us to further comment on. In spite of stagnation in the number of establishments, manufacturing registered steady progress in employment, peaking in 1983 when it recorded 67,103 persons. 1984 seemed a bad year as employment in manufacturing dipped to 59,001 persons. In terms of gross output, the record was more glamorous with a steady and rapid pace of increase from 1,360 million patacas in 1978 to 5,865 million patacas in 1984, i.e. a $331 \%$ increase. By value-added, the progress was equally spectacular with a $366 \%$ increase for the same period (1978-84). The decline of manufacturing employment in 1983-84 was strangely matched with substantial increases in gross output and valueadded. However, this may be due partly to inflation and partly to some upward movement of the products in price and/or quality value. At this juncture, it is appropriate to point out that the industrial censuses have not returned gross output and value-added for all the reported establishments. The number of establishments that reported this information is less than complete, particularly for the very small ones employing less than five persons. Less than $50 \%$ of such small establishments returned data on gross output and value-added. Besides, the contribution by the various sized sectors to gross output and value-added in manufacturing have not been listed in all the census reports. Instead, there is only a list by sizebreakdown for all industries, which includes manufacturing, mining and utilities. We have to estimate the amount contributed by the non-manufacturing sectors to produce the size breakdown for Table 6 concerning gross output, value-added and for productivity.

If we define small as 0-99 persons, then $81.8 \%$ of Macau manufacturing belong to the small category. Medium (100-499 persons) and large factories (500 and more persons) are few in number. In 1983, they had respectively $17.7 \%$ and $0.4 \%$ of the total factory employees. So Macau factories are predominantly small, and SMI (Small and Medium Industries), by our definition, account for about $99.6 \%$ of the total number of factories.

In 1983, SMI accounted for close to 40,000 jobs, equivalent to 
$22.8 \%$ of the estimated total employment for 1985. The total employment provided by them exceeded the combined contributions of construction, tourism, gambling, commerce, finance, fishing and farming and transport, storage and communication. This underlines the significance of labour-intensive manufacturing in Macau towards employment generation. Among SMI, the larger bulk of employment is concentrated within the size brackets of 50199 persons i.e. the small-medium (Table 6). They contributed $50.9 \%$ of total manufacturing jobs in 1983. Petty firms employing less than 10, though much more numerous in establishment number, are in fact not very significant in employment generation. They accounted only for 1.9\% of total manufacturing employment (though as noted in Table 6, some of those factories might not have returned data on this).

Measured by value of gross output, SMI achieved a share of 90.1\% of manufacturing total in 1983 (Table 6), much more significant than the larger industries. Again, the bulk of SMI contributions was concentrated in the small-medium (50-199 persons) establishments which were responsible for as much as $49.5 \%$ of total manufacturing output.

Measured by value-added, the contribution by SMI may be easily related to GDP, as value-added is an important basis for its calculation. If we use the share of total value-added by SMI in manufacturing in 1983 as a proxy for SMI's share in the proportion of GDP accounted for by manufacturing in 1984. (Table 2) then SMI's contribution to GDP in 1984 is estimated to be $29.1 \%$. That amount is larger than the contribution by tourism (with gambling). SMI's economic role should therefore not be slighted. In fact, it may be said that modern industrialization in Macau has been the development of export-oriented small and medium industries and at present these industries have become the chief pillar in Macau both in terms of employment and GDP contribution.

As a flexible form of industrial organization, SMI may be the better way for instantaneous response to the sudden market opportunities which have so much characterized Macau's postWorld War II industrialization. The seasonal variations of demand for the dominant products such as knitwear, other garments, toys, etc. are easily observed. In the 1987 small and medium industry 
survey, it is reported that $48.1 \%$ of the factories received an order once or more than once a week, while $22.1 \%$ claimed that their orders are unstable. A high degree of flexibility and an ability of quick delivery to meet rush orders characterized small firms. Furthermore offering and receiving subcontracts among factories enhances the industrial division of labour making possible efficiency in small size production. SMI may also be efficient, from the point of view of its utilization of labour at the skill level required by the majority of Macau's industries as they do not require skills of long periods from formal and on-the-job training. Small scale operation of individual firms therefore enhances the adaptability of Macau manufacturing to the outside demand situation and is also complementary to the supply side considerations (other than labour) on which Hong Kong has much influence.

\section{Conclusion}

The special geo-political setting of Macau had generated, before World War II, a peculiar economy based on the "special industries". Modernization and industrialization in the post-war period changed the basics of Macau's economy much, turning it into a growing centre for export-oriented light industries. However, the major factors for this new development still lie with Macau's peculiar geopolitical situation. Nevertheless, Macau's small size, in both territory and population, and its low quality labour, a consequence of longtime neglect in technical and tertiary education, as well as its inadequate international communication and transport systems, have so conditioned it that manufacturing in present day Macau functions largely as an out-processing system, or in fact an adjunct of Hong Kong, depending heavily on the comparative advantages of cheap labour, quotas for major exports and preferential tariffs offered by the key markets under GPS. From this point of view, the nature of Macau manufacturing has been disadvantageously straight-jacketed in product range, and in market and technological range by the requirements of Hong Kong investors who dominate Macau manufacturing, making Macau's industries highly labour- 
intensive, with low level of value-added and composed largely of small and medium sized establishments engaging mostly in simple assembling.

By Macau's own standards, however, the growth of exportoriented industries may have been a great success, especially so when considering its rate of growth, quick response to market changes as reflected in shifts in market and product concentration and its major contribution towards local employment and GDP. However, the process of growth has only taken the form largely of quantitative increase of goods manufactured, with little deepening in terms of technology and local entrepreneurship. This is one of the adverse consequences of over-dependence on Hong Kong which also undermined the otherwise, natural demand for building up Macau's own marketing and other industrial supporting capabilities. To a very large extent, industrialization in Macau has been driven by the domestic factor advantages of cheap labour and separate quota and tariff status, together with the cost-minimization motivations of Hong Kong's direct investment. In a way this is very close to a system of international subcontracting by multinational cooperations for the manufacture of low-cost parts and products for the international market which limits the possibility for the development of forward or backward linkages in the domestic economy of the host country. A good case has been described for the Philippines..$^{30}$ However, in the horizon new market forces and cheap labour havens in the vicinity of Macau are already making their impacts increasingly felt and threaten the future prospects of such type of industrialization.

The open door policy of China has led to a much expanded possibility in the Pearl River Delta for the development of exportoriented light manufacturing. There are evidence that Hong Kong industrialists are already increasing their out-processing activities in the Delta. Macau's position as Hong Kong's out-processing area is thus under the very serious threat posted by the Pearl River Delta where land and labour are much cheaper. It has been estimated that by 1987, about one million persons had already been employed by joint-venture and processing establishments in the Delta which are mainly financed or based on processing orders from Hong Kong. With the coming of 1999 and the gradual integration of Macau and 
the Delta, the comparative edge of its cheap labour would diminish. At least one of its post-war driving forces in light manufacture, export-oriented industrialization would therefore phase out in significance. On top of this, international protectionism, though still hitting directly at the Asian NICs, is gradually affecting Macau exports as well. How should Macau face such new challenges? In addition, within Macau itself, the key factor of production - labour is increasingly short in supply and hence also becoming expensive. There are suggestions by the local industrial community to upgrade technology and to improve labour skill. Could these work in Macau, if the nature of Macau manufacturing remains unchanged? These are important questions which would seriously affect the health and well-being of its entire manufacturing economy and perhaps also of its prospects in the foreseeable future.

The purpose of this paper may serve to present the general background through the qualitative account of Macau's post-war industrial growth. Further insights into the nature and prospects of Macau's industrialization and an attempt to answer the above questions would require further research.

Victor F.S. Sit is Reader in the Department of Geography and Geology, University of Hong Kong.

\section{NOTES}

1 James Petras, "Towards a Theory of Industrial Development in the Third World," Journal of Contemporary Asia, Vol. 14, 1984, pp. 182-203.

2 Dai-chang Ho and Hung-qi Miu, The Geography of Macau (in Chinese) (Guangzhou: College of Science and Arts, Guangdong Province, 1946).

3 J.M. Braga, Macau (Macau: Information and Tourism Department, 1970).

4 C.S. Chen, "Macau", Geography Research Paper Series, No. 36 (Hong Kong: Chinese University of Hong Kong, 1970) (mimeographed).

5 C.J. Pang, F.S. Sit and C.L. So, (in Chinese), Hong Kong and Macau
(Hong Kong: Commercial Press, 1986), Chapter 19.

6 Ibid.

7 Braga, Macau, p. 36.

8 Almanac of Macau's Economy 1983 (in Chinese) (Macau: Journal "Va Kio," 1985).

9 A. Pinho, "Gambling in Macau", in R.D. Cremer, ed., Macau: City of Commerce and Culture (Macau: University of East Asia, 1986), pp. 15564.

10 Economic Services, Macau Government, Quarterly Economic Bulletin (First Quarter, 1987).

11 Economic Services, Macau Govern- 
ment, Macau: Overall Economic Developments and Prospects 1986 (Macau, 1987).

12 See Chen, "Macau."

13 See L.T. Wells, "Foreign Investment from the Third World: The Experience of Chinese Firms from Hong Kong", Columbia Journal of World Business (Spring 1978), pp. 39-49; P. Luey, "Hong Kong Investment," in H. Hughes and P.S. You, eds., Foreign Investment and Industrialization in Singapore (Canberra: ANU, 1969), pp. 112-139; E.K.Y. Chen, "Hong Kong Multinationals in Asia: Characteristics and Objectives," in K. Kumar and M.G McLeod, eds., Multinationals from Third World Countries (Lexington: Health, 1981); and E.K.Y. Chen, "Multinationals from Hong Kong," in S. Lall, ed., The New Multinationals (Wiley, 1983), pp. 88-268.

14 R. Feitor, "Macau's Modern Economy," in Cremer, ed., Macau: City of Commerce and Culture (Macau: University of East Asia, 1986), pp. 139. 154 and Sectorial Policies, Investment Plans (Public Sector) 1984 (Macau: Government of Macau, 1984), p. 94.

15 Feitor, "Macau's Modern Economy," pp.139-154.

16 Ibid., p. 142.

17 Almanac of Macau's Economy 1984-86 (in Chinese) (Macau: Journal "Va Kio," 1987), p. 26.

18 Chen, "Multinationals from Hong Kong," pp. 88-268.

19 V.F.S. Sit, R. Cremer and S.L. Wong, Changes in the Industrial Structure and the Role of Small and Medium Industries in Asian Countries: The Case of Macau (Tokyo: Institute of Developing Economics, 1988).

20 R. Feitor, "Macau's Modern Economy," p. 45.

21 Almanac of Macau's Economy 1984-86, p. 53.

22 R. Feitor, "Macau's Modern Economy," p. 141.

23 Almanac of Macau's Economy 1984-86, p. 24.

24 Ibid., pp. 59-68.
25 lbid., pp. 83-85.

26 Ibid., pp. 90-91.

27 Sit, Cremer and Wong, Changes in the Industrial Structure and the Role of Small and Medium Industries in Asian Countries: The Case of Macau.

28 Ibid.

29 Recenseamento Industrial (Census of Industry) (Macau: Macau Government, various dates).

30 R.E. Ofreneo, "Contradictions in Export-led Industrialization: the Philippine Experience," Journal of Contemporary Asia, Vol. 14, 1984, pp. 484-495. 